\title{
HOSTS OF CERTAIN NEW YORK TICKS
}

By George Anastos

Biological Laboratories, Harvard University

The records of ticks contained in this paper are based upon material collected by Mr. R. V. Nardy and Mr. William M. Machado under the general supervision of Dr. Donald L. Collins of the New York State Science Service.

The collection was made at the eastern end of Long Island, New York, from May 10, 1946, to September 9, 1946, at three stations: Montauk Point, Hither Hills State Park, and Hook Pond (East Hampton). It comprised 992 larvæ, nymphs and adults, the following species being represented: Dermacentor variabilis (Say), Hamaphysalis leporis-palustris (Packard), Ixodes cookei Packard, Ixodes dentatus Neumann, Ixodes muris Bishopp and Smith, and Ixodes scapularis Say.

The host distribution represented by this survey is extensive and includes 17 species of birds and mammals. The ticks were taken mostly from trapped or shot animals; only a few specimens were dragged from grass or taken off people. The host distribution is as follows :

\section{BiRds $^{1}$}

Catbird, Dumetella carolinensis (Linnæus).-Ixodes muris (16 nymphs, 2 larvæ off 6 birds).

Brown thrasher, Toxostoma rufum (Linnæus).-Ixodes muris (9 $\mathrm{n}$. off 1 bird).

Eastern or American robin, Turdus migratorius migratorius Linnæus.-Ixodes muris (22 n. off 2 birds).

Red-eyed towhee, Pipilo erythrophthalmus erythrophthalmus (Linnæus.)-Ixodes muris (18 n., 9 l. off 2 birds).

Eastern song sparrow, Melospiza melodia melodia (Wilson).-Ixodes muris (6 n., 1 l. off 3 birds).

1 Bequaert, J. C. 1946. The Ticks or Ixodoidea, of the Northeastern United States and Eastern Canada. Entomologica Americana, XXV, No. 2, pp. 73-232. 


\section{MammaLs}

Short-tailed shrew, Blarina brevicauda aloga Bangs.Dermacentor variabilis (1 l. off 1 shrew); Ixodes muris (4 n., 9 l. off 6 shrews).

Long-tailed shrew, Sorex parvus (Say) (= cinereus True).-Dermacentor variabilis ( 1 l. off 1 shrew); Ixodes muris (6 l. off 1 shrew).

Raccoon, Procyon lotor lotor (Linnæus)._Ixodes muris (1 n. off 1 raccoon).

Skunk, Mephitis nigra (Peale and Beauvois).-Dermacentor variabilis ( 1 male, 3 females off 1 skunk); Ixodes muris (69 n. off 1 skunk).

Red fox, Vulpes fulva (Desmarest).-Ixodes cookei (5 n. off 1 fox) ; Ixodes muris (29 n., 1 l. off 1 fox).

Man (accidental host).-Ixodes muris (1 n., 1 l.) ; Ixodes scapularis (1 female).

Chipmunk, Tamias striatus lysteri (Richardson).Ixodes muris (54 n. off 2 chipmunks).

Gray squirrel, Sciurus carolinensis carolinensis (Gmelin). Dermacentor variabilis (1 $\mathrm{n}$. off 1 squirrel); Ixodes muris (125 n., 4 l. off 4 squirrels).

White-footed or deer mouse, Peromyscus leucopus fusus Bangs.-Dermacentor variabilis (17 n., 29 l. off 22 mice); Ixodes muris (138 n., 105 l. off 33 mice).

Meadow mouse, field mouse, or vole, Microtus pennsylvanicus pennsylvanicus (Ord.)-Dermacentor variabilis (6 n., 3 l. off 9 mice); Ixodes muris (5 females, 15 n., 12 l. off 10 mice).

Eastern cottontail rabbit, Sylvilagus floridanus mearnsi (Allen).-Dermacentor variabilis (1 male, 2 females, $1 \mathrm{n}$. off 3 rabbits); Hamaphysalis leporis palustris (42 males, 18 females, 13 n., 14 l. off 9 rabbits); Ixodes dentatus (9 males, 12 females, 15 n., 2 l. off 8 rabbits); Ixodes muris (66 n., 34 l. off 7 rabbits).

Virginia deer, Odocoileus virginianus borealis (Miller). -Ixodes muris (18 n. off 1 deer).

Dragged from the grass.-Dermacentor variabilis (1 female); Ixodes scapularis (10 males, 4 females).

During this survey Ixodes muris has been observed and recorded for the first time from the long-tailed shrew, 
gray squirrel, Eastern cottontail rabbit, red fox, chipmunk, raccoon, skunk, Virginia deer, red-eyed towhee, catbird, Eastern or American robin, and brown thrasher. This makes twelve new hosts for the larval and nymphal forms of Ixodes muris Bishopp and Smith. Also recorded for the first time was the larval form of Dermacentor variabilis (Say) from the long-tailed shrew. This represents the first record of any species of tick taken from the long-tailed shrew in the Northeastern United States.

All identifications recorded for the first time were verified by Dr. Joseph C. Bequaert, Curator of Insects, Museum of Comparative Zoölogy, to whom the writer is indebted for his kind and valuable assistance.

\section{Sphindide and Ciside (colleoptera)}

During May, 1945, species of this family were found swarming in the small, crowded, woody fungi on standing dead and fallen trees and also stumps. There were many of what appears to be Sulcacis lengi Dury, Cis fuscipes Mellie, Ennearthron thoracicorne Zieg., Octotemnus lavis Csy., and Sphindus americanus Lec. They had about all disappeared by the end of June in Mass. About the same species and under the same conditions were found at Paris, Me., with the addition of Eurysphindus denticollis Lec., which occurred in a flat, brown fungus of a soft smut-like consistency on a partly uprooted poplar in the woods. This has been taken before on the same species of fungus on the top of a stump at Monmouth, Me., June 27, 1912.-C. A. Frost. 

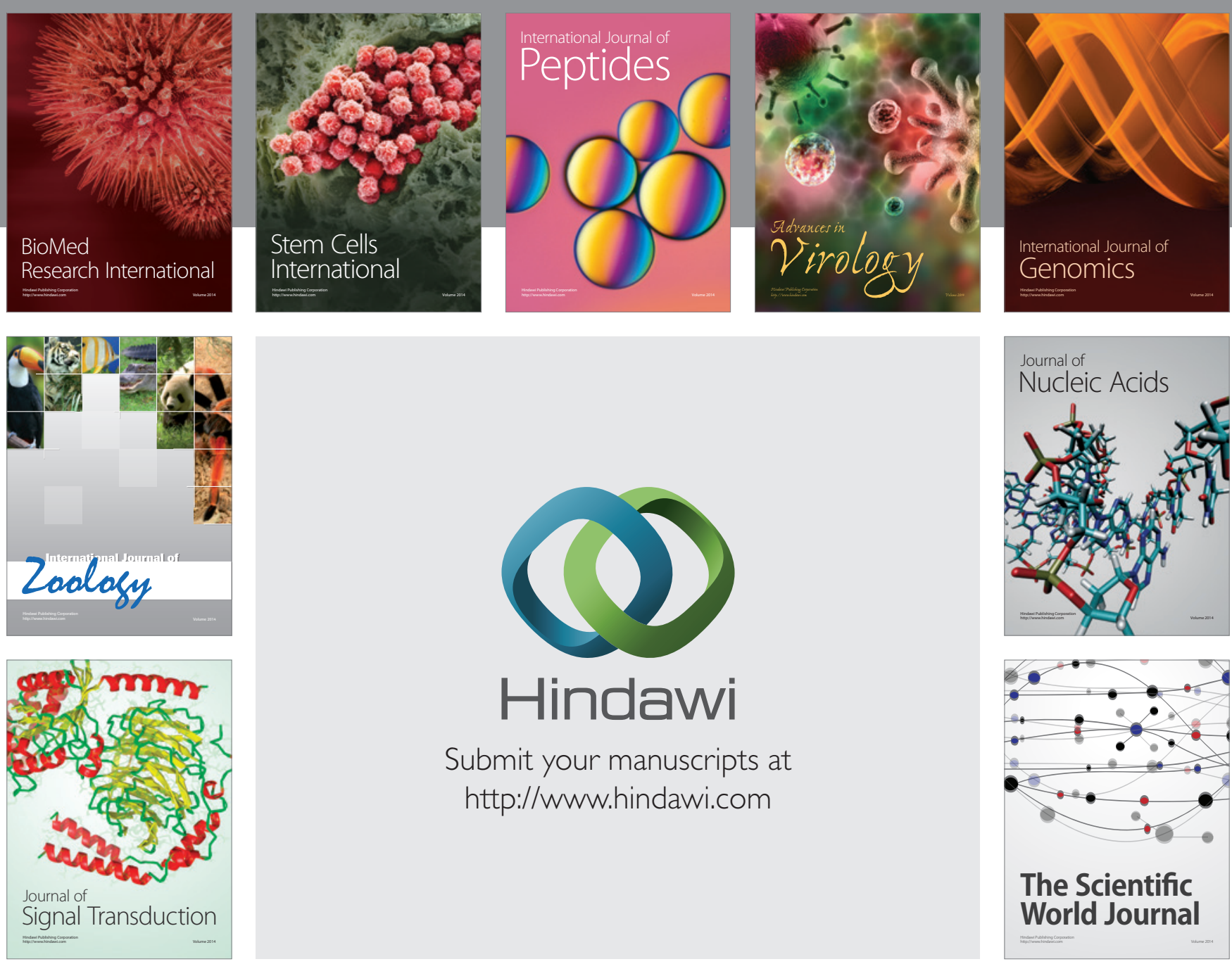

Submit your manuscripts at

http://www.hindawi.com
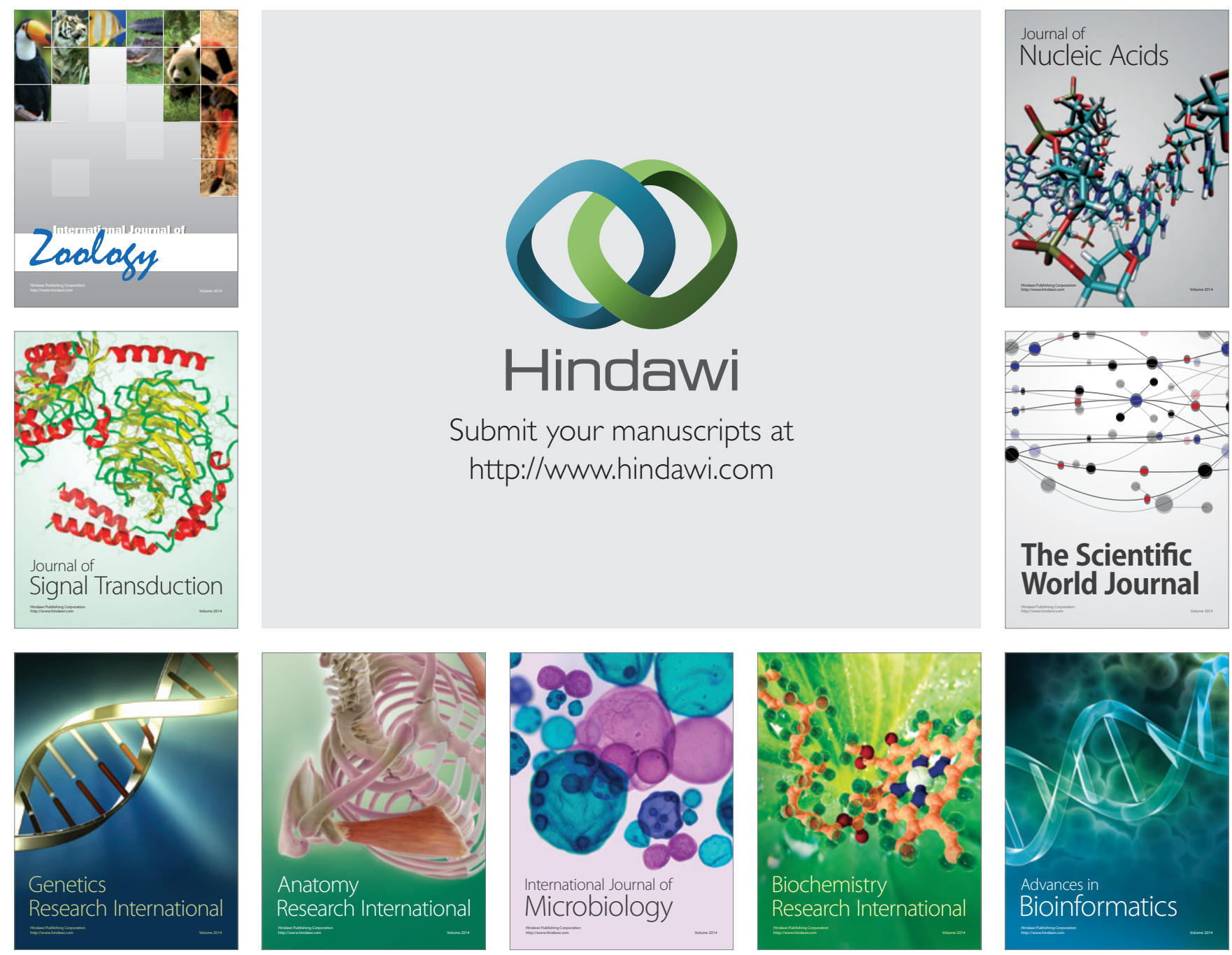

The Scientific World Journal
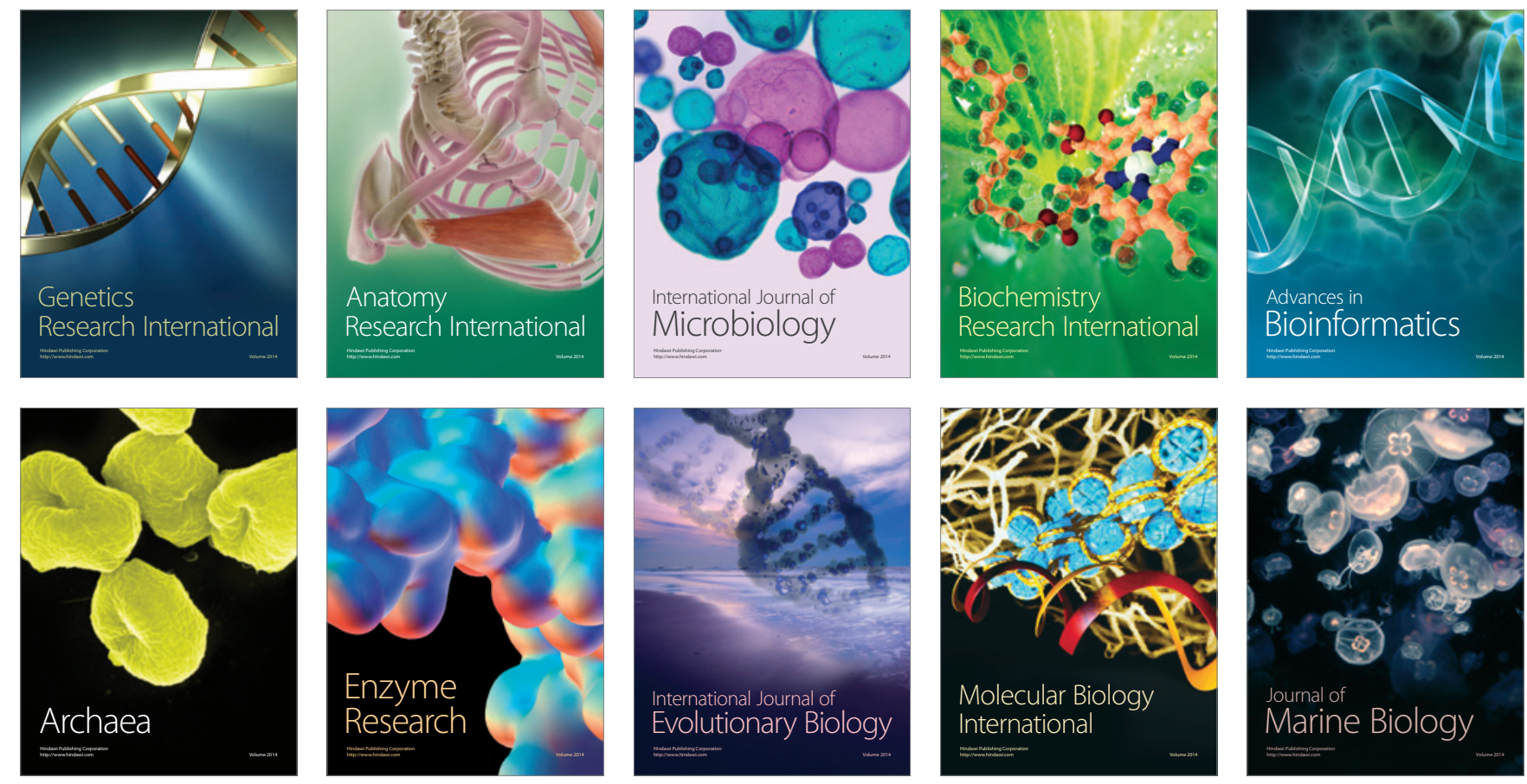